\title{
UPAYA PENANGGULANGAN EROSI DAN TANAH LONGSOR MENGGUNAKAN LIMBAH SABUT KELAPA DI DUSUN KLUI, DESA MALAKA
}

\author{
Kornelia Webliana B ${ }^{1}$, Diah Permata Sari'1), Solikatun ${ }^{2)}$ \\ 1)Fakultas Pertanian Universitas Mataram, Mataram, Nusa Tenggara Barat, Indonesia \\ ${ }^{2)}$ Prodi Sosiologi Universitas Mataram, Mataram, Nusa Tenggara Barat, Indonesia \\ Corresponding author : Kornelia \\ E-mail :-yeniwebliana@gmail.com
}

\section{Diterima 22 September 2020, Direvisi 19 Oktober 2020, Disetujui 19 Oktober 2020}

\begin{abstract}
ABSTRAK
Sebagian besar wilayah Dusun Klui, Desa Malaka memiliki topografi wilayah yang berbukit untuk areal perkebunan dan topografi datar untuk pemukiman. Salah satu potensi perkebunan yang cukup melimpah yang dimiliki Desa Malaka adalah kelapa. Sejauh ini pemanfaatan kelapa masih terpaku pada hasil primer, yaitu air dan daging kelapa serta tempurung kelapa untuk arang. Limbah sabut kelapa belum dimanfaatkan, padahal memiliki nilai ekonomi dan ekologi yang dapat membantu untuk meningkatkan pendapatan masyarakat dan keberlanjutan dari ekosistem. Salah satu bentuk pemanfaatan limbah sabut kelapa berupa cocomesh memiliki fungsi penting dalam pencegahan erosi dan longsor pada kelerengan curam. Tujuan dari kegiatan ini adalah untuk meningkatkan nila ekonomi dan ekologi limbah sabut kelapa dalam bentuk cocomesh sebagai alternatif pencegahan erosi dan longsor di Dusun Klui Desa Malaka. Metode yang digunakan untuk mencapai tujuan tersebut, yaitu sosialisasi dan pelatihan pembuatan cocomesh. Hasil kegiatan pengabdian pada masyarakat menunjukkan bahwa limbah perkebunan berupa sabut kelapa dapat diolah menjadi cocomesh yang bernilai ekonomi dan ekologi. Masyarakat Dusun Klui mendapatkan pengetahuan dan wawasan setelah dilakukan sosialisasi mengenai penangan limbah sabut kelapa untuk pencegahan erosi. Masyarakat Dusun Klui juga mendapatkan pengetahuan dan keterampilan dalam mengolah limbah sabut kelapa menjadi cocomesh dan mempraktikannya dalam pemasangan cocomesh di lahan perkebun yang memiliki tingkat kecuraman yang tinggi.
\end{abstract}

Kata kunci : cocomesh; erosi; longsor.

\begin{abstract}
Most of the Klui Hamlet, Malacca Village, has a hilly topography for plantation areas and a flat topography for settlements. One of the potential plantations that is quite abundant in the village of Malacca is coconut. So far, coconut utilization is still focused on primary products, namely water and coconut meat and coconut shell for charcoal. Coconut husk waste has not been utilized, even though it has economic and ecological value that can help to increase community income and the sustainability of the ecosystem. One form of utilization of coconut husk waste in the form of cocomesh has an important function in preventing erosion and landslides on steep slopes. The purpose of this activity is to improve the economic and ecological value of coconut husk waste in the form of cocomesh as an alternative to erosion and landslide prevention in Klui Hamlet, Malacca Village. The methods used to achieve these objectives are socialization and training in making cocomesh. The results of community service activities show that plantation waste in the form of coconut husks can be processed into cocomesh which has economic and ecological value. The people of Klui Hamlet gained knowledge and insight after socialization was carried out on coconut husk waste handlers for erosion prevention. The people of Klui Hamlet also gain knowledge and skills in processing coconut husk waste into cocomesh and practice it in installing cocomesh on sloping garden land.
\end{abstract}

Keywords : cocomesh; erosion; landslide.

\footnotetext{
PENDAHULUAN

Kelapa merupakan salah satu tanaman perkebunan yang potensial untuk dikembangkan. Di Indonesia, kelapa mempunyai peran dalam kehidupan baik secara ekonomi, sosial dan budaya. Menurut BPS (2012) hingga tahun 2011 luas areal
}

tanaman kelapa tercatat 3.709,1 ribu hektar dan didominasi oleh perkebunan rakyat. Komposisi sabut kelapa sekitar $35 \%$ dari keseluruhan buah kelapa yang terdiri dari $75 \%$ serat dan $25 \%$ gabus (pitch) yang menhubungkan antar serat (Nurhilal \& Suryaningsih, 2018). Satu 
buah kelapa dapat diperoleh rata-rata $0,4 \mathrm{~kg}$ sabut yang mengandung $30 \%$ serat. Sabut kelapa terdiri dari serat dan gabus.

Desa Malaka merupakan pemekaran dari Desa Pemenang Barat Kecamatan Pemenang, yang terletak di ujung barat Kabupaten Lombok Utara, perbatasan antara Kabupaten Lombok Utara dengan Kabupaten Lombok Barat. Luas wilayah Desa Malaka adalah 3.970,30 $\mathrm{Ha}$ atau $12,41 \mathrm{Km}^{2}$ yang pemanfaatannya antara lain, pemukiman 130,30 $\mathrm{Ha}$, tanah perkebunan sekitar $1669 \mathrm{Ha}$, lahan investor sekitar $279 \mathrm{Ha}$ dan bangunan perkantoran $1 \mathrm{Ha}$. Desa ini memiliki topografi wilayah yang berbukit yang digunakan untuk areal perkebunan dan topografi wilayah datar untuk pemukiman. Desa ini memiliki Perkebunan Kelapa dan Potensi Sumberdaya Manusia dengan jumlah penduduk sekitar 9.054 Jiwa dengan jumlah Kepala Keluarga sekitar 2.856 yang terdiri dari Laki 4.850 orang dan Perempuan 4.737. orang (Profil Desa Malaka, 2019).

Dusun Klui merupakan salah satu dusun di kawasan Desa Malaka yang memiliki wilayah perbukitan dengan kecuraman yang cukup tinggi. Hal ini tentu saja membutuhkan perhatian yang lebih dari pemerintah setempat, mengingat kawasan dataran rendah di Dusun dijadikan sebagai kawasan permukiman bagi masyarakat. Dusun Klui memiliki potensi perkebunan yang cukup tinggi khususnya tanaman kelapa. Letak geografis Dusun yang berada di pesisir pantai, mengakibatkan tanaman kelapa tumbuh subur dan menjadi komoditi utama sumber pendapatan masyarakat. Sejauh ini pemnfaatan kelapa hanya terpaku pada hasil primernya saja, baik dalam bentuk kelapa segar maupun batok kelapa sebagai bahan utama pembuatan arang untuk membakar ikan, hal ini kemudian mengakibatkan tingginya limbah sabut kelapa di pemukiman masyarakat Dusun Klui.

Limbah Sabut kelapa dapat bernilai ekologi dan ekonomi jika dimanfaatkan dengan baik. Salah satu cara untuk meningkatkan pendapatan petani kelapa dan sekaligus juga dapat dijadikan sebagai langkah penghijauan/reklamasi terhadap erosi dan degradasi adalah dengan memanfaatkan produk sampingan dan atau limbah kelapa misalnya cocomesh. Cocomesh merupakan jaring yang dibuat dari sabut kelapa, biasanya dibuat dengan ukuran yang sama dengan net bola volly atau disesuaikan dengan kebutuhan (Indahyani, 2011). Cocomesh merupakan material yang ramah lingkungan karena mudah terurai (Sunandar \& Prananda, 2020) sehingga relatif aman digunakan sebagai upaya konservasi tanah dan air pada lahan miring. Penggunaan Cocomesh terbukti efektif dalam pencegahan erosi dan longsor dengan cara dihamparkan pada kawasan yang memiliki kelerengan tinggi. Cocomesh dapat menahan laju aliran permukaan penyebab erosi serta mempertahankan kelembapan tanah. Penerapan cocomesh juga telah dilakukan di dusun-dusun Luhu, Maluku untuk upaya pencegahan longsor pada lahan pertanian masyarakat yang rata-rata memiliki kelerengan $30-50$ derajat (Rahardjo et al., 2017). Tujuan dari kegiatan ini adalah meningkatkan nilai ekonomi dan ekologi dari limbah sabut kelapa dan sebagai salah satu alternatif pencegahan erosi dan tanah longsor di Dusun Klui Desa Malaka.

\section{METODE}

Kegiatan upaya pencegahan erosi dan longsor menggunakan limbah sabut kelapa (cocomesh) ini dilaksanakan pada bulan Agustus 2020, berlokasi di Dusun Klui, Desa Malaka, Kecamatan Pemenang, Kabupaten Lombok Utara. Metode yang digunakan dalam kegiatan ini yaitu dengan cara sosialisasi/ penyampaian materi secara langsung oleh tim yang meliputi materi :

1. Urgensi penanganan limbah sabut kelapa,

2. Urgensi pencegahan erosi dan longsor,

3. Tata cara pembuatan cocomesh.

Selanjutnya dilaksanakan kegiatan pelatihan pembuatan cocomesh yang didampingi langsung oleh tim pengabdian. Peserta kegiatan pengabdian ini adalah masyarakat sekitar Dusun Klui Desa Malaka, yang dipilih berdasarkan perwakilan dari pemuda dan beberapa kepala keluarga. Pelaksanaan penyuluhan dan pelatihan mengikuti prosedur pencegahan Covid 19 yaitu dengan menyediakan tempat untuk cuci tangan dan sabun cuci tangan di dekat balai dusun, membagikan masker penutup hidung dan mulut kepada peserta dan menganjurkan untuk tetap menjaga jarak satu dengan lainnya.

\section{HASIL DAN PEMBAHASAN}

Pengabdian masyarakat dengan tema upaya penanggulangan erosi dan tanah longsor menggunakan limbah sabut kelapa di Dusun Klui, Desa Malaka dihadiri oleh 25 anggota masyarakat yang tediri dari kepala dusun dan masyarakat yang diwakili oleh kepala keluarga dan perwakilan pemuda. Kegiatan pengabdian diawali dengan penyampaian materi dengan metode ceramah dan diskusi. Materi yang disampaikan terdiri dari pokok bahasan sebagai berikut : urgensi penanganan limbah sabut kelapa, urgensi pencegahan erosi dan longsor di lahan masyarakat yang memiliki kelerengan curam dan pengenalan cocomesh dan cara pembuatannya. Pemilihan materi disesuaikan 
dengan kebutuhan masyarakat yang belum pernah mendapatkan materi mengenai cocomesh dan pengelolaan limbah sabut kelapa. Hasil dari kegiatan pengabdian dapat digambarkan sebagai berikut:

\section{A. Urgensi Penanganan Limbah Sabut Kelapa}

Sabut kelapa merupakan bagian terluar dari buah kelapa atau yang biasa disebut sebagai selimut buah kelapa. Jika dilakukan kegiatan penguraian, sabut kelapa akan menghasilkan serat sabut (cocofibre) dan serbuk sabut (cococoir). Sabut kelapa dapat diolah menjadi beragam produk jadi dan setengah jadi yang memiliki nilai jual tinggi. Produk tersebut antara lain: tali sabut, keset, serat sabut (cocofibre), serbuk sabut (cocopeat), serbuk sabut padat (cocopeatbrick), cocomesh, cocopot, cocosheet, coco fiber board (CFB) dan cococoir. Sejauh ini pemanfaatan sabut kelapa di Dusun Klui masih belum dilakukan secara maksimal. Kurangnya pengetahuan dan pelatihan terkait pemanfaatan sabut kelapa mengakibatkan masih tingginya limbah sabut kelapa di kawasan ini. Penanganan limbah sabut kelapa penting untuk dilakukan untuk mencegah terjadinya pencemaran lingkungan akibat membusuknya limbah sabut kelapa serta mengatasi polusi udara akibat tingginya aktivitas pembakaran limbah sabut kelapa. Berikut ini merupakan gambaran pemberian materi terkait urgensi penanganan limbah sabut kelapa di Dusun Klui.

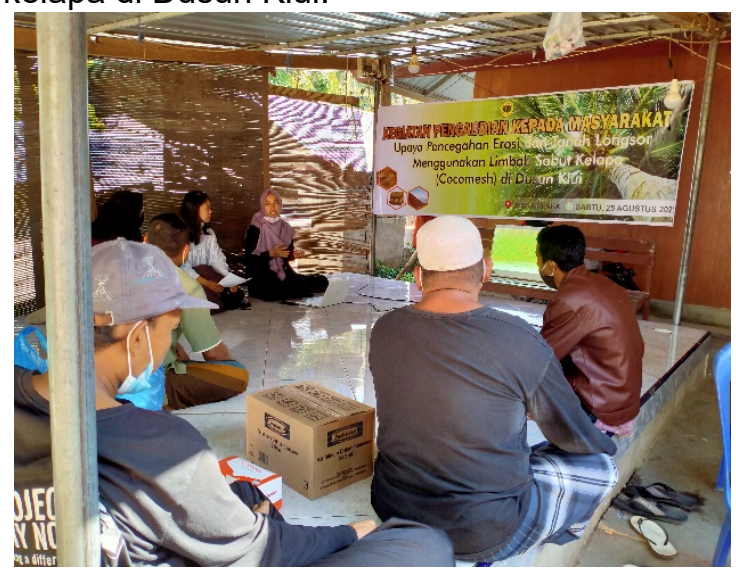

Gambar 1. Sosialisasi Penyampaian Materi

Penyampaian materi diharapkan dapat mengedukasi masyarakat terkait bahaya limbah sabut kelapa bagi ekosistem. Selain itu tujuan dari penyampaian materi juga untuk membuka wawasan dan pengetahuan dari masyarakat terkait nilai ekonomi dari limbah sabut kelapa yang dapat dimanfaatkan oleh masyarakat untuk meningkatkan penghasilan.

\section{B. Urgensi pencegahan erosi dan longsor di lahan masyarakat yang memiliki kelerengan curam}

Erosi merupakan peristiwa berpindahnya tanah atau bagian-bagian tanah dari suatu tempat ke tempat lain oleh media alam, seperti: angin dan air. Pada daerah beriklim tropika basah seperti di Indonesia proses erosi umumnya disebabkan oleh air, sedangkan pada daerah yang beriklim kering penyebab utama terjadinya erosi adalah angin (Arsyad, 2010). Proses terjadinya erosi ditentukan oleh faktor-faktor hidrologi terutama intensitas hujan, topografi, karakteristik tanah, vegetasi penutup lahan, dan tata guna lahan.

Sebagai salah satu kawasan yang memiliki tingkat kecuraman yang cukup tinggi, Dusun Klui membutuhkan perhatian khusus untuk mencegah terjadinya erosi pada wilayah ini. Salah satu upaya yang dapat dilakukan yaitu dengan memanfaatkan limbah sabut kelapa untuk dijadikan sebagai cocomesh. Limbah sabut kelapa yang dihasilkan oleh masyarakat desa dapat dibentuk seperti jaring dengan ukuran yang bervariasi sesuai dengan kebutuhan lahan. Menurut Munir (2017), rongga-rongga cocomesh dapat berukuran 3 $\mathrm{cm} \times 3 \mathrm{~cm}$ atau disesuaikan dengan kondisi lahan maupun permintaan khusus.

Penggunaan Cocomesh ini terbukti efektif dalam mencegah longsor ataupun banjir. Cara kerja cocomesh yaitu mempertahankan kelembapan tanah di bawah hamparan lahan sehingga tempat tersebut dapat menjadi media tumbuh bagi rumput dan jenis perdu lainnya. Menurut Sunandar \& Prananda (2020), kombinasi cocomesh dengan coirblanket dalam teknik hydroseeding sangat efektif mengurangi erosi permukaan pada lahan miring sampai dengan $99,4 \%$ sebelum vegetasi atau tanaman menutupi permukaan lahan atau lereng.

Pemasangan dapat dilakukan pada kawasan yang memiliki kecuraman yang tinggi dengan mematok ujung dari cocomesh. Berikut ini merupakan gambaran kemiringan lahan di Dusun Klui. 


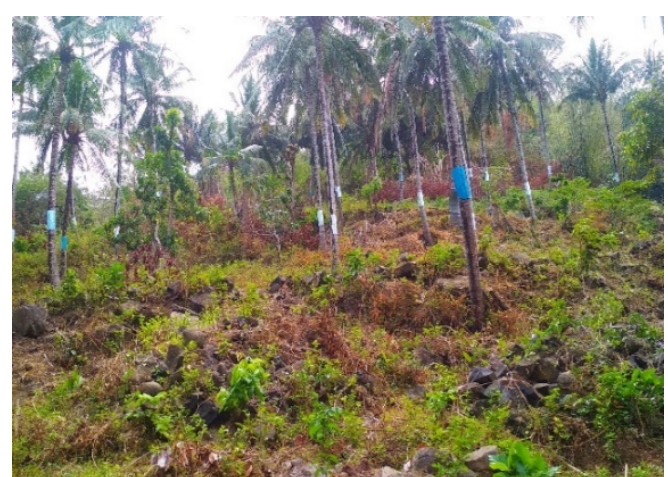

Gambar 2. Kemiringan lahan di dalam kawasan perkebunan

\section{Pengenalan Cocomesh dan cara pembuatannya}

Pada tahapan ini pemateri mendampingi masyarakat dalam kegiatan pembuatan cocomesh, adapaun tahapan kegiatan adalah sebagai berikut :

1. Pembuatan tali sabut kelapa yang dilakukan secara manual tanpa menggunakan alat bantu seperti alat pencacah sabut kelapa dan alat pemintal.

2. Pembuatan cocomesh

3. Pemasangan cocomesh pada areal yang memiliki kecuraman di sekitar kawasan Dusun Klui.

Tahapan kegiatan tersebut dapat dijelaskan sebagai berikut :

\section{Pembuatan Tali Sabut kelapa}

Proses pembuatan tali sabut kelapa idealnya dilakukan menggunakan alat yaitu alat pengurai sabut kelapa dan alat pemintal tali. Namun pada pelatihan ini proses pembuatan tali sabut kelapa dilakukan secara manual sehingga membutuhkan waktu yang cukup lama. Oleh karena itu untuk menunjang proses pembuatan cocomesh pemateri juga mendatangkan bahan tali dari daerah lain. Proses pembuatan tali diawali dengan cara mengeringkan sabut kelapa selama 2-3 hari. Kemudian bagian lapisan dalam (endocarpium) yang mengandung seratserat halus kemudian dikeluarkan atau dipisahkan dengan bagiaan luar. Hasil dari pemisahan diperoleh serat-serat halus yang pendek yang kemudian diikat dan dijalin sehingga diperolehlah bentuk serabut kelapa yang berbentuk tali.

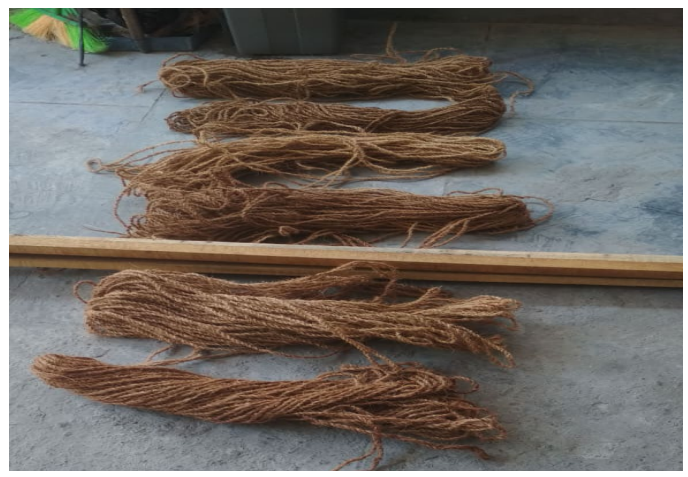

Gambar 3. Tali Sabut Kelapa

\section{Tahapan Pembuatan Cocomesh}

Proses pembuatan cocomesh dapat dilakukan dengan ukuran yang bervariasi. Proses pembuatan cocomesh diawali dengan membentuk mesh dengan jaran 5 $\mathrm{cm}$ antar jaring dengan panjang $10 \times 10$ meter. Pembuatan mesh ini dilakukan dengan tujuan untuk memudahkan masyarakat dalam menjalin tali sabut kelapa menjadi cocomesh. Pada saat pelatihan masyarakat tertarik dan antusias untuk mencoba dan berdiskusi terkait pembuatan cocomesh dan pemasangannya di lahan. Masyarakat mengikuti seluruh rangkaian kegiatan dengan semangat dan terlibat aktif dengan diskusi dan praktik. Program kegiatan ini berhasil menarik minat masyarakat untuk dapat mengolah limbah sabut kelapa yang sebelumnya belum pernah mereka ketahui.

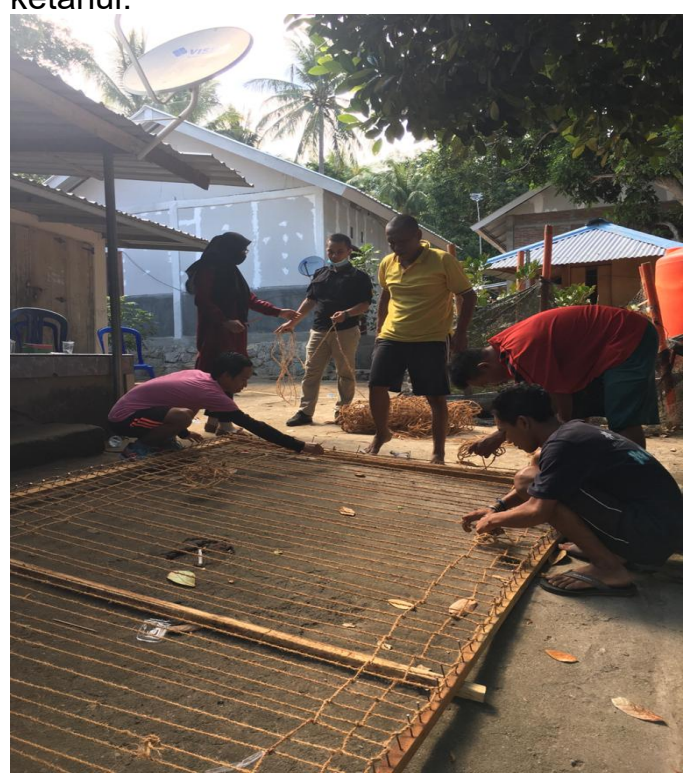

Gambar 4. Pelatihan Pembuatan Cocomesh

3. Pemasangan Cocomesh

Setelah dilakukan kegiatan pembuatan cocomesh, dilanjutkan dengan pemasangan cocomesh di lapangan. Lahan yang dipilih merupakan kebun milik 
masyarakat yang memiliki tingkat kecuraman yang tinggi dan berada dekat dengan wilayah pemukiman. Pemasangan cocomesh di area ini diharapkan dapat mencegah terjadinya erosi atau pengikisan tanah yang dapat berdampak pada wilayah pemukiman. Berikut ini merupakan proses pemasangan cocomesh di salah satu wilayah yang memiliki kecuraman di Dusun Klui

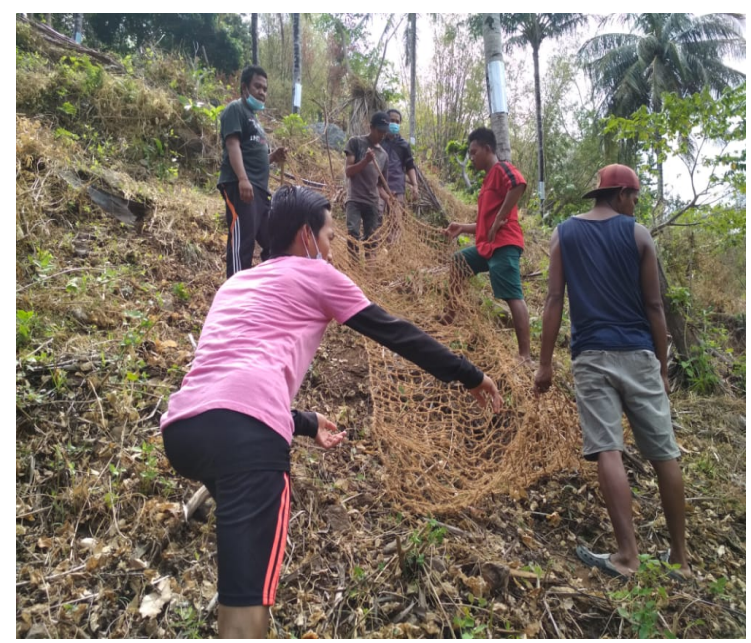

Gambar 5. Proses pemasangan Cocomesh bersama masyarakat

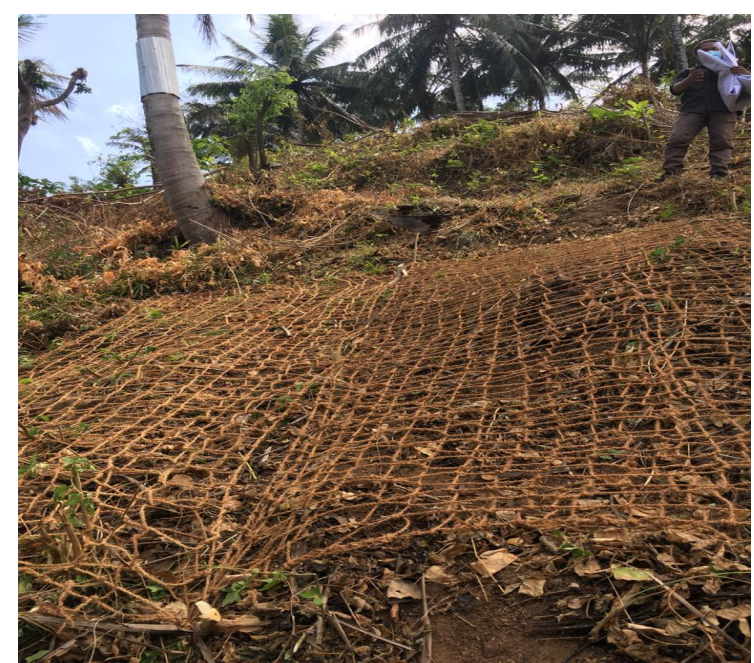

Gambar 6. Cocomesh di hamparan lahan

Berdasarkan hasil evaluasi pelaksanaan kegiatan, terdapat beberapa faktor pendukung dalam pelaksanaan kegiatan ini antara lain : kesediaan perangkat desa hingga dusun untuk membantu dan bekerja sama dalam pelaksanaan kegiatan, kepala dusun dan sekertaris desa Malaka banyak membantu dan mendukung kelancaran kegiatan, serta antusiasme masyarakat dalam mengikuti penyuluhan dan pelatihan yang diberikan. Selain itu, ada pula faktor penghambat dalam kegiatan pengabdian ini yaitu keterbatasan waktu pelaksanaan dan kesulitan tim pengabdian untuk mencari bahan yang telah jadi yang akan dijadikan contoh kepada masyarakat. Bahan jadi hanya dapat diperoleh dari luar Nusa Tenggara Barat.

Hasil kegiatan pengabdian dengan tema "Upaya Penanggulangan Erosi dan Tanah Longsor dengan Menggunakan Limbah Sabut Kelapa" antara lain :

a. Ketercapaian tujuan pelatihan Kegiatan ini menyebabkan masyarakat mengetahui bahwa limbah sabut kelapa dapat dimanfaatkan dan memiliki nilai ekonomi dan ekologi, dan tertarik untuk mencoba membuatnya.

b. Ketercapaian materi yang direncanakan

Seluruh materi yang direncanakan telah dapat disampaikan dengan baik walaupun tidak secara detail karena keterbatasan waktu yang tersedia.

c. Antusias Masyarakat dalam Pelatihan Pembuatan Cocomesh Masyarakat tertarik untuk mencoba dan bekerja sama membuat dalam pelatihan pembuatan cocomesh.

\section{SIMPULAN DAN SARAN}

Berdasarkan hasil kegiatan, maka dapat disimpulkan bahwa kegiatan sosialisasi dan pelatihan pemanfaatan limbah sabut kelapa menjadi cocomesh dapat memberikan pengetahuan dan keterampilan baru bagi masyarakat Dusun Klui, Desa Malaka untuk meningkatkan nilai ekonomi dan ekologi dari limbah sabut kelapa dan sebagai salah satu alternatif pencegahan erosi dan tanah longsor. Permasalahan yang dihadapi pada saat dilakukan kegiatan pengabdian yaitu, terbatasnya alat untuk membuat bahan tali dari sabut kelapa, sehingga mengakibatkan proses pembuatan tali membutuhkan waktu yang cukup lama dengan peralatan yang sangat terbatas. Saran yang dapat diberikan yaitu keberlanjutan kegiatan serupa dalam bentuk pendampingan, sosialisasi dan membuka peluang pasar sehingga produk yang dihasilkan dapat dikenal oleh masyarakat luas. Selain itu bantuan alat pemintal benang dan pengurai sabut kelapa juga perlu mendapatkan perhatian dari pemerintah guna memaksimalkan proses peningkatan nilai ekonomi sabut kelapa di Desa Klui, Dusun Malaka.

\section{DAFTAR RUJUKAN}

Arsyad, S. (2010). Konservasi Tanah \& Air. In Konservasi Tanah dan Air (p. 496).

BPS. (2012). Statistik Indonesia 2012. 
Indahyani, T. (2011). Pemanfaatan Limbahn Sabut Kelapa pada Perencanaan Interior dan Furniture yang Berdampak pada Pembedayaan Masyarakat Miskin. Humaniora, 2(1), 15-23.

Munir, M. D. (2017). Aplikasi Green Sabo dalam Pengendalian Erosi di Kawasan Lahan Bagian Atas. Jurnal Teknik Hidraulik, 8(2), 87-100.

Nurhilal, O., \& Suryaningsih, S. (2018). Pengaruh Komposisi Campuran Sabut dan Tempurung Kelapa terhadap Nilai Kalor Biobriket dengan Perekat Molase. Jurnal IImu Dan Inovasi Fisika, 2(1), 814.

Rahardjo, A. P., Sujono, J., Saputra, A., Murwono, J., Priyosulistyo, Pramumijoyo, S., ... Daryanto, D. (2017). Penguatan Kapasitas Masyarakat di Pulau-Pulau Kecil dalam Pengurangan Resiko Bencana. In Prosiding Seminar Nasional Pengurangan Risiko Bencana (pp. 104-121).

Sunandar, A., \& Prananda, I. A. (2020). Penerapan Teknologi Hydroseeding Dikombinasi dengan Matras Organik di Lereng Jalan Bebas Hambatan Manado-Bitung. Jurnal Himpunan Pengembangan Jalan Indonesia, 6(2), 105-118.

Profil Desa. (2019). Profil Desa Malaka. Kecamatan Pemenang Kabupaten Lombok Utara. 